\title{
ANÁLISE DA BACIA HIDROGRÁFICA DO RIO IRAÍ (PR): DESLIZAMENTOS EM ENCOSTAS, PREVISÃO DE ENCHENTES E PROCESSOS DE EROSÃO'.
}

\author{
Claudinei Taborda da Silveira ${ }^{2}$
}

$\mathrm{Na}$ configuração do cenário brasileiro, os três principais fenômenos geoambientais de risco e prejuízos a população são as enchentes, os deslizamentos em encostas e os processos de erosão. Todos têm sua origem na relação de desequilíbrio da ocupação do homem sobre a natureza, ocasionando mudanças na dinâmica da paisagem. As enchentes geralmente ocorrem em áreas de aglomeração urbana. Os fatores que contribuem para sua ocorrência são: excessiva impermeabilização do solo, ocupação desordenada próxima ou sobre o leito dos rios e inadequados sistemas construídos para a drenagem das águas pluviais. Os deslizamentos são de grande incidência, tanto os de origem natural, como também os induzidos por cortes para implantação de moradias, desmatamentos, atividades de mineração, etc. Os processos erosivos significam um grande problema para a sociedade, embora a erosão dos solos tenha causas relacionadas à própria natureza da região, é por meio da ação humana que os processos tendem a se acelerar. Assim, o presente projeto propõe uma abordagem sistemática de tais fenômenos dentro da unidade espacial delimitada por uma bacia hidrográfica, utilizando da aplicação de modelagem geoambiental. Seu avanço está na integração e abordagem desses fenômenos em uma mesma unidade geográfica utilizando de método determinístico para diagnóstico e prognóstico visando aplicação no planejamento e gestão ambiental. Para tanto utilizará da modelização do ciclo hidrológico, partindo da avaliação dos parâmetros físicos e morfométricos. Serão utilizados como ponto de partida os métodos de modelagem para previsão de enchentes, estabilidade de vertentes e do limiar da erosão. A aplicação dos modelos e sua espacialização serão realizadas em um Sistema de Informações Geográficas. A área de estudo adotada é a bacia do Rio Irai, pois a mesma apresenta características físiconaturais potenciais para a ocorrência de tais fenômenos, também por situar-se junto a um cenário de constantes transformações antropogênicas, a Região Metropolitana de Curitiba.

PALAVRAS-CHAVE: enchentes; deslizamentos; erosão

\footnotetext{
${ }^{1}$ Orientadora: Prof $^{\mathrm{a}} \mathrm{Dr}^{\mathrm{a}}$ Chisato Oka-Fiori

2 Doutorando em Geografia (UFPR) - e-mail: claudineits@pop.com.br
} 